\title{
Polymorphisms and Their Haplotype Combinations in the Lysozyme Gene Associated with the Production Traits of a Chinese Native Chicken Breed
}

\section{-Author(s)}

\section{Yan LJ!"I \\ Fang $X T^{\prime}$ \\ Liu $Y^{\prime}$ \\ Zhang $C L$ \\ Chen $\mathrm{H}^{\prime}$}

Institute of Cellular and Molecular Biology, Jiangsu Normal University, Xuzhou, Jiangsu 221116, China

" Nantong College of Science and Technology, Nantong, Jiangsu 226007, China

\section{ABSTRACT}

Animal lysozymes, which have been studied in many of invertebrate and vertebrate species, have been characterized and demonstrated to be immune-associated molecules, digestive enzymes and multifunctional molecules. The purpose of this study was to detect the connection between lysozyme-gene polymorphism and the production traits of a Chinese native chicken breed (Langshan chicken). Four single nucleotide mutation sites were identified: G345A, C1726T, G1836A, A1838G. By the linkage disequilibrium analysis, six haplotypes and 15haplotype combinations were depicted in the studied population. The statistical analysis demonstrated that the SNPs and the haplotype combinations are related to body weight at sixteen weeks of age in Langshan chickens $(p<0.05)$, and those with combined haplotype Hap3-Hap6 (GA-TT-GGAA) presented higher body weight. Our study demonstrated that the SNPs and their haplotype combinations in the lysozyme gene were associated with the chicken production traits, and that SNPs can be used as a molecular marker for chicken marker-assisted selection.

\section{INTRODUCTION}

Lysozyme is a ubiquitous enzyme defined as muramidase that catalyzes the hydrolysis of 1,4-betalinkages between $\mathrm{N}$-acetylmuramic acid and $\mathrm{N}$-acetyl-D-glucosamine in bacterial peptidoglycan, a major component of the bacterial cell wall (Phillips, 1966). According to their type-specific amino acid sequence and their species of origin, lysozymes have been categorized into three main types in the animal kingdom: the c-type (chicken or conventional type), the g-type (goose-type), and the i-type (invertebrate type) lysozyme (Callewaert \& Michiels, 2010; Nilsen \& Myrnes, 2001). These animal lysozymes have been studied in many species of invertebrates and vertebrates and have been characterized and demonstrated to be immune-associated molecules (RoxströmLindquist et al., 2004), digestive enzymes (Grunclovà et al., 2003), and multifunctional molecules (Ursic Bedoya et al., 2005). C-type lysozymes are the main lysozymes produced by most vertebrates, including mammals. the mechanism of enzyme action has been studied most thoroughly in the c-type lysozyme from hen egg white, which has served as a model for studies on enzyme structure and function (Sassi et al., 2011; Sugimoto et al., 2011; Swaminathan et al., 2001).

The chicken lysozyme gene, the first cloned and characterized eukaryotic lysozyme gene (Baldacci et al., 1979; Jung et al., 1980; Lindenmaier et al., 1979), is one of the most thoroughly studied model genes for investigations of the molecular mechanisms involved in cell- and stage-specific transcriptional regulation (Peters et al., 1989). The gene is expressed in the tubular gland cells of oviduct of laying chickens and it is under the control of steroid hormones (Bonifer et al., 1990; Schiitz et al., 1978). It is also constitutively expressed in mature macrophages (Peters et 
al., 1989). This gene, mapped on chicken's chromosome 1, spans 3688bp and its sequence organization with four exons and three introns is homologous to the human lysozyme gene and the human $\alpha$-lactalbumin gene (https://www.ncbi.nlm.nih.gov).

The objective of the research was to identify single nucleotide polymorphisms (SNPs) of the lysozyme gene in a Chinese well-known native chicken breed (Langshan chicken) and to implement the SNP haplotypes construction and relationship analysis to investigate the effects of the lysozyme gene on chicken production traits.

\section{MATERIAL AND METHODS}

\section{Ethics statement}

The Institutional Animal Care and Use Committee (IACUC) of the School of Life Science of Jiangsu Normal University approved the animal study proposal, with the permit number: SYXK (Su) IACUC 2011-0039. All chicken experimental procedures were performed in accordance with the Regulations for the Administration of Affairs Concerning Experimental Animals approved by the State Council of the People's Republic of China.

\section{Samples and data collection}

In this study, 300healthy hens of a Chinese native chicken breed (Langshan chicken) reared in Rudong chicken farm, Jiangsu province, were randomly selected. These hens were reared in cages and were fed with commercial corn-soybean diets. Body weight at 16 weeks of age (16-week BW) and the total number of eggs produced in 300 days(300-day EN) were recorded by the farm workers.

Whole blood samples were collected from the wing vein in vacuum blood collection tube (anticoagulant EDTA) and submitted to the laboratory in an icebox. Genomic DNA was extracted according to method of Müllenbach et al. (1989). These DNA samples were then dissolved in sterile distilled water and stored at $-18^{\circ} \mathrm{C}$ until analyses.

\section{Mutation detection}

Based on the chicken lysozyme gene sequence (GenBank accession number FJ542564), four pairs of primers to amplify three exons, partial intron regions, partial 5' untranslated regions (UTR), and partial 3' UTR (Table 1) were designed using the Primer Premier 6.0 software. Each amplification reaction was carried out in a $15-\mu \mathrm{L}$ volume: $0.6 \mu \mathrm{L}$ genomic DNA (50 ng/ $\mu \mathrm{L}), 0.6 \mu \mathrm{L}$ of each primer (10 pmol/ $\mu \mathrm{L}), 7.5 \mu \mathrm{L} 2 \times$ Reaction Mixture, and $0.12 \mu \mathrm{L}$ Taq DNA polymerase $(2.5 \mathrm{U} / \mu \mathrm{L})$ (Tiangen, China), $5.58 \mu \mathrm{L}$ nuclease-free water. PCR reactions were carried out using PTC-200PCR Thermal Cyclers (MJ Research, Inc., USA). Thermo-cycling comprised an initial step of $5 \mathrm{~min}$ at $95^{\circ} \mathrm{C}$ and 33 cycles of $50 \mathrm{~s}$ at 94 ${ }^{\circ} \mathrm{C}$ for, $50 \mathrm{~s}$ at annealing temperature (Table 1), $50 \mathrm{~s}$ at $72{ }^{\circ} \mathrm{C}$, and a final extension at $72^{\circ} \mathrm{C}$ for $10 \mathrm{~min}$.

Mutations were scanned using the single-strand conformation polymorphism (SSCP) method. Firstly, 5 $\mu \mathrm{L}$ denaturation reagent composed of xylene-cyanole $(0.025 \%)$, bromophenol blue $(0.025 \%)$, formamide (95\%), and EDTA (25 mM) was mixed with $5 \mu \mathrm{L}$ of the PCR products. Secondly, the mixture was heated at $98{ }^{\circ} \mathrm{C}$ using PTC-200 PCR Thermal Cyclers (MJ Research, Inc.) for $10 \mathrm{~min}$ and immediately chilled on ice. Lastly, denatured DNA was loaded on $10 \%$ PAGE (polyacrylamide gel, $80 \times 73 \times 0.75 \mathrm{~mm}$ ) in $1 \times$ trisborate EDTA(TBE) buffer at constant voltage (200V) for $2.5 \mathrm{~h}$, and then gels were stained with $0.1 \%$ silver nitrate. After the polymorphism was detected, the PCR fragments of different SSCP patterns were purified and sequenced in a DNA sequencer (ABI PRISM 377, Applied Biosystems, ThermoFisher Scientific, USA).

\section{Data analyses}

Genotypic frequencies, allelic frequencies and Hardy-Weinberg equilibriums (HWE) were directly

Table 1 - Genetic variants identified in the lysozyme gene of Langshan chicken population

\begin{tabular}{|c|c|c|c|c|c|c|c|}
\hline Primer sets & Primer sequences (from $5^{\prime}$ to $3^{\prime}$ ) & $\begin{array}{c}\text { Annealing } \\
\text { temperature }\left({ }^{\circ} \mathrm{C}\right)\end{array}$ & $\begin{array}{l}\text { Product } \\
\text { length }(b p)\end{array}$ & $\begin{array}{c}\text { Region of } \\
\text { amplified fragment }\end{array}$ & SNPs & $\begin{array}{l}\text { Mutation } \\
\text { location }\end{array}$ & Mutaition type \\
\hline P1 & $\begin{array}{l}\text { F: TAAAAGAAGAGGCAGGTG } \\
\text { R: TGTCTACATTCCAACATCA }\end{array}$ & 58 & 301 & $\begin{array}{l}\text { Partial } 5^{\prime} \text {-UTR, exon } 1 \\
\text { and partial intron } 1\end{array}$ & g. $345 G>A$ & Exon 1 & Silent \\
\hline P2 & $\begin{array}{l}\text { F: TAAAATAATAATCTTTGAGG } \\
\text { R: TTGTTCTGCTTTGTTCTA }\end{array}$ & 55 & 317 & $\begin{array}{l}\text { Partial intron 1, exon } \\
2 \text { and partial intron } 2\end{array}$ & $\begin{array}{l}\text { g. } 1726 C>T \\
\text { g. } 1836 G>A \\
\text { g. } 1838 A>G\end{array}$ & $\begin{array}{l}\text { Exon } 2 \\
\text { Intron2 } \\
\text { Intron2 }\end{array}$ & $\begin{array}{c}\text { Silent } \\
\text { Non-coding } \\
\text { Non-coding }\end{array}$ \\
\hline P3 & $\begin{array}{l}\text { F: GCCAACACCAACACGCACTG } \\
\text { R: GAACCCCCCGCCACCTAC }\end{array}$ & 68,5 & 161 & $\begin{array}{l}\text { Partial intron 2, exon } \\
3 \text { and partial intron } 3\end{array}$ & & No SNPs & \\
\hline P4 & $\begin{array}{l}\text { F: AGATCGTCAGCGATGGAAACG } \\
\text { R: CGCGGCAGCTCCTCACAG }\end{array}$ & 65 & 194 & $\begin{array}{l}\text { Partial intron 3, exon } \\
3 \text { and partial } 3^{\prime} \text {-UTR }\end{array}$ & & No SNPS & \\
\hline
\end{tabular}

asNPs: single nucleotide polymorphisms 
computed. Population diversity parameters, including gene heterozygosity ( $\mathrm{He})$, effective allele numbers ( $\mathrm{Ne})$, and polymorphism information content (PIC) were calculated. He and Ne were computed using POPGENE software (Version 3.2), while PIC was computed according to Botstein et al., (1980).

Two different programs were used in sequence to construct haplotypes from SNP genotypes of the chicken population. HAPLOVIEW software (Version 4.2) was used to reconstruct haplotypes (Barrett et al., 2005), while PHASE computer program (Version 2.1) was used to obtain haplotypes and haplotype frequencies (Huang et al., 2010; Stephens et al., 2001).

The effects of the SNPs and haplotypes on the production traits were calculated using the general linear model (GLM) procedure of SPSS software (Version 17.0) (Yan et al., 2013). The model was:

$$
\text { Trait }_{i j}=\mu+X i+F j+\varepsilon_{i j}
$$

where Trait 1 ij: 16-week BW and 300-day EN; $\mu=$ mean of the trait in the population; $X_{i}=$ fixed effect of genotype or combined haplotype; $F_{i}=$ fixed effect of hatch and $\varepsilon_{\mathrm{ij}}=$ the random residual.

Least-squares means of each genotype and combined haplotype and the corresponding standard errors were calculated. Variance homogeneity of all the data was tested before multiple comparisons. Homoscedastic data were submitted to Duncan's multiple-range test. When data were not homoscedastic, Dunnett's T3 test was applied.

\section{RESULTS AND DISCUSSION}

\section{Identification of genetic variants}

We amplified four loci of the Langshan chicken lysozyme gene, including all four exons, 5'UTR-exon boundaries, exon-intron boundaries, and intron-3'UTR boundaries (Table 1). Polymorphisms were detected at the P1 and P2 loci of the lysozyme gene using the SSCP method. Three genotypes (named GG, GA, and AA) were clearly discerned at the P1 locus (Figure 1), while five patterns (designated $A A, A B, B B, A C$ and $C C$ ) were observed at P2 locus (Figure 2). The polymorphic DNA amplification fragments were sequenced. Compared with the sequence previously reported in the GenBank (GenBank Accession number:FJ542564), four SNPs (SNP1 g.345G>A; SNP2 g.1726C>T; SNP3 g.1836G>A; SNP4 g.1838A $>\mathrm{G}$ ) were identified in these chickens (Figure 3). The mutation location and type of the four SNPs are shown in Table 1 . The SNP1 resulting in a synonymous mutation, GCG (28Ala)>GCA (28Ala), was located in exon 1. The SNP2 in exon 2 was also a synonymous mutation, TAC(71Tyr)>TAT(71Tyr). The other two SNPs (SNP3 and SNP4) in intron 2 were the non-coding mutations. Most of the previous studies focused on two aspects: 1) the association analyses between the lysozyme protein and the chicken growth traits, 2) the structure and regulation mechanism of the chicken's lysozyme gene. There are few studies on the effects of the lysozyme gene mutation on production traits of chickens. Hou et al. (2010) found three SNPs in the lysozyme gene of the Jinghai yellow chicken population (another Chinese indigenous chicken breed). Two of the three SNPs identified (g.345G>A in exon1, g.1726C $>T$ in exon2) were identical to those found in the present study. However, the other mutation (g. 1660T>C in exon2) was not detected in the chicken breed studied here. These results show a difference in the structure of the lysozyme gene between the two Chinese native breeds.

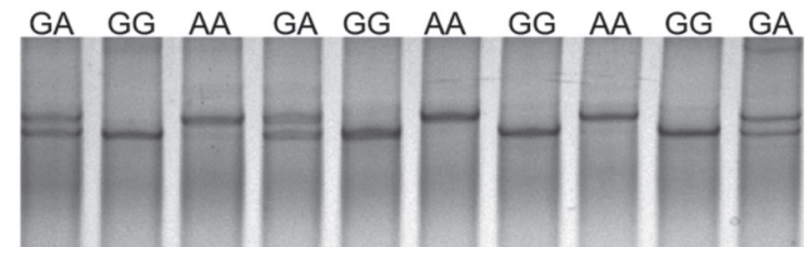

Figure 1 - PCR-SSCP patterns of P1 locus of the Langshan chicken lysozyme gene.

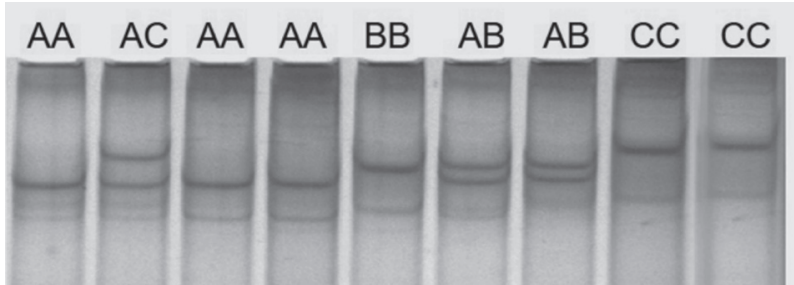

Figure 2 - PCR-SSCP patterns of P2 locus of the Langshan chicken lysozyme gene.

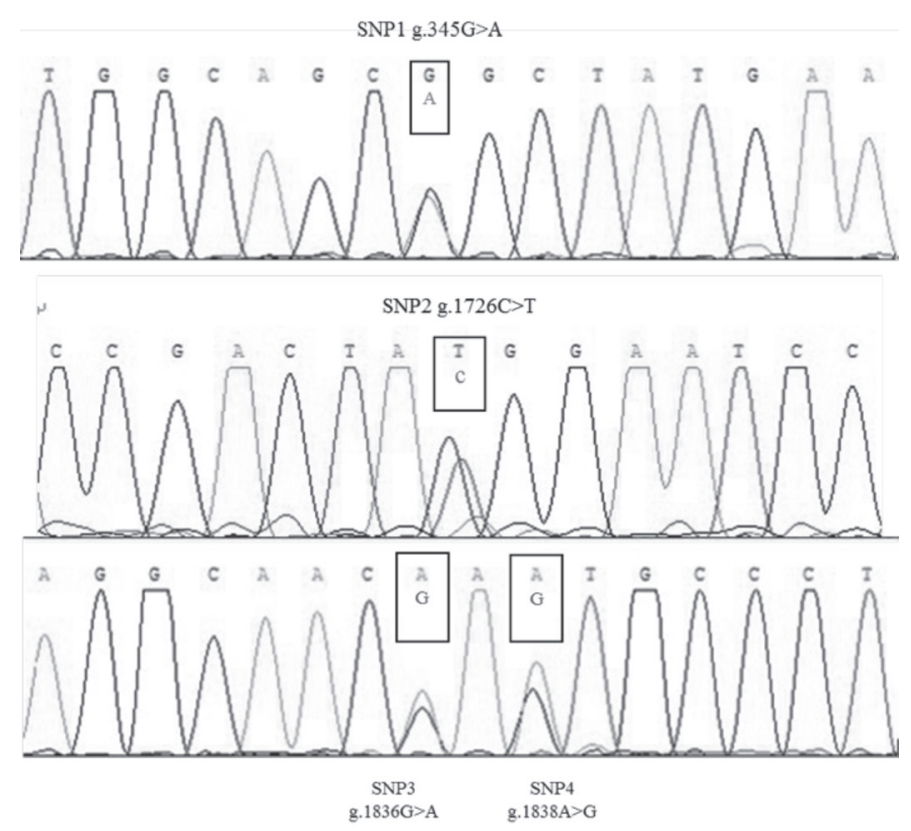

Figure 3 - Sequence results of the four SNPs within the lysozyme gene in Langshan chicken. 


\section{Diversity analysis}

Genotype frequencies, allele frequencies, value of $\chi 2$ test, He, Ne, and PIC for the P1 and P2 loci were are listed in Table 2. At the P1 locus, allele G was the dominant allele, and the genotype GG was the dominant genotype. At the P2 locus, allele A was the dominant allele and the genotype AA was the dominant genotype. In order to estimate the quality or informativeness of a gene locus as a genetic marker, He and PIC are often used, and PIC has become the most widely used measure since its first application (Nagy et al., 2012). At the two loci (P1 and $\mathrm{P} 2)$, the Langshan chicken population belonged to intermediate genetic diversity (PIC classification: $\mathrm{PIC}<$ 0.25 , low polymorphism; $0.25<\mathrm{PIC}<0.5$, intermediate polymorphism; and $\mathrm{PIC}>0.5$, high polymorphism). In addition, the Chi-square test demonstrated that, at the two loci, this native chicken breed was not in HardyWeinberg equilibrium $(p<0.05)$, which may be possibly explained by the fact that, as a native breed specially protected and developed by the local government during the last few years, the Langshan chicken population has been under high selection pressure. The sustained artificial selection by the government eventually resulted in an increase in the gene frequency of alleles favored by selection, such as the lysozyme gene (Yan et al., 2015).

\section{Haplotype analysis and extent of linkage disequilibrium}

In Figure 4, extent of linkage disequilibrium (LD) between every two of the four SNPs was estimated, and indicated that the LD between pairs of loci varied from complete disequilibrium to almost no disequilibrium.

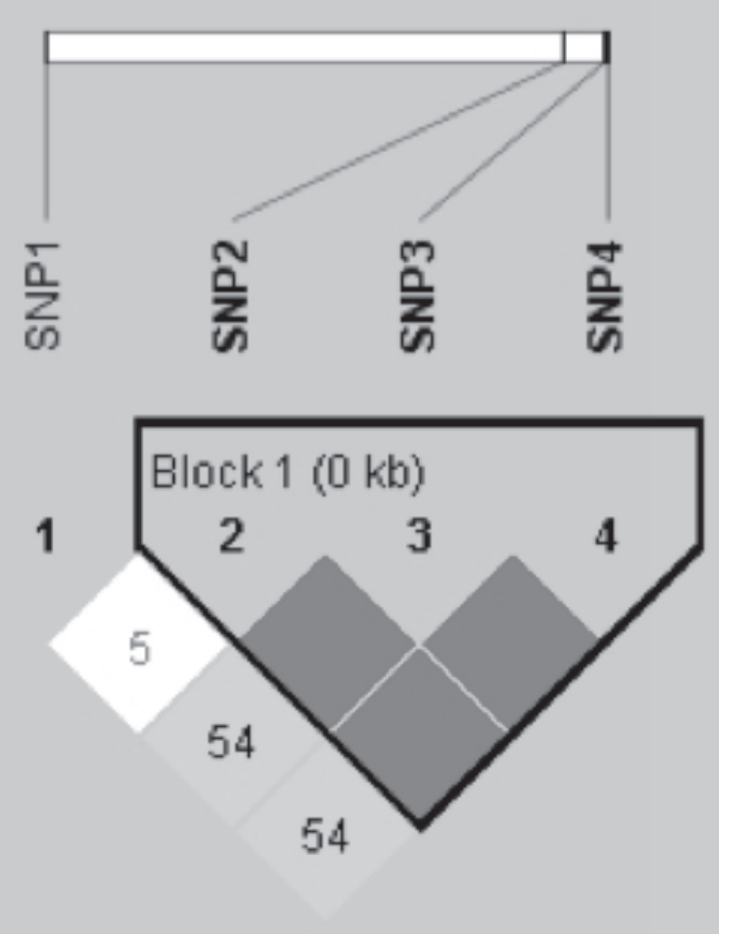

Figure $4-L D$ across the SNPs visualized by the Haploview software. Each diamond contained the level of LD measured by "Standard (D'/ LOD)" between the SNPs specified. Redder tones correspond to increasing levels of $D^{\prime}$. Values in the cells represented pairwise $D^{\prime}$ values (\%), while empty cells indicated that pairwise $D^{\prime}$ equalled to one between the corresponding SNPS.

Color scheme was demonstrated according to Haploview standard (D'/LOD) scheme, and a haplotype block formed with the three SNPs (SNP2, SNP3 and SNP4) was identified in the study. The estimated values of linkage disequilibrium analysis among the four SNPs are shown in Table 3. The $D^{\prime}$ values varied from 0.050 to 1.000 , while the $r^{2}$ values ranged from 0.002 to 1.000 . The $D^{\prime}$ value between any two of the three SNPs (SNP2, SNP3 and SNP4) was 1.000. Only the $r^{2}$

Table 2 - Genotype frequencies, allele frequencies, value of $\chi 2$ test, $\mathrm{He}, \mathrm{Ne}$ and PIC of the lyzosyme gene in Langshan chickens

\begin{tabular}{|c|c|c|c|c|c|c|c|c|c|c|c|c|}
\hline Loci & & Genoty & be frequenci & (Number) & & All & frequer & & $\chi^{2}(\mathrm{HWE})^{\mathrm{a}}$ & $\mathrm{He}^{\mathrm{b}}$ & $\mathrm{Ne}^{\mathrm{c}}$ & $\mathrm{PIC}^{\mathrm{d}}$ \\
\hline P1 & $\begin{array}{c}G G \\
0.700(210)\end{array}$ & & $\begin{array}{c}\text { GA } \\
0.213(64)\end{array}$ & & $\begin{array}{c}\text { AA } \\
0.087(26)\end{array}$ & $\begin{array}{c}G \\
0,807\end{array}$ & & $\begin{array}{c}A \\
0,193\end{array}$ & $30.4056(p<0.05)$ & 0,2133 & 1,4533 & 0,2630 \\
\hline P2 & $\begin{array}{c}\text { AA } \\
0.547(164)\end{array}$ & $\begin{array}{c}A B \\
0.220(66)\end{array}$ & $\begin{array}{c}\text { BB } \\
0.053(16)\end{array}$ & $\begin{array}{c}A C \\
0.150(45)\end{array}$ & $\begin{array}{c}C C \\
0.030(9)\end{array}$ & $\begin{array}{c}A \\
0,732\end{array}$ & $\begin{array}{c}B \\
0,163\end{array}$ & $\begin{array}{c}C \\
0,105\end{array}$ & $29.1865(p<0.05)$ & 0,2700 & 1,7451 & 0,3860 \\
\hline
\end{tabular}

${ }^{\mathrm{a}} \chi 2$ (HWE): Hardy-Weinberg equilibrium $\chi 2$ value,H ardy-Weinberg disequilibrium $(\mathrm{p}<0.05)$; ${ }^{\mathrm{H}} \mathrm{He}$ : gene heterozygosity

cNe: effective allele numbers; ${ }^{~} P I C$ : polymorphism information content

Table 3 - Linkage values estimated in the disequilibrium analysis among four SNPs identified in the lysozyme gene of the studied population

\begin{tabular}{|c|c|c|c|c|c|c|}
\hline SNPS ${ }^{a}$ & SNP $1 / 2$ & SNP $1 / 3$ & SNP $1 / 4$ & SNP 2/3 & SNP 2/4 & SNP 3/4 \\
\hline $\mathrm{D}^{\prime}$ & 0,050 & 0,546 & 0,546 & 1,000 & 1,000 & 1,000 \\
\hline LOD & 0,200 & 10,670 & 10,670 & 5,180 & 5,180 & 73,990 \\
\hline$r^{2}$ & 0,002 & 0,146 & 0,146 & 0,023 & 0,023 & 1,000 \\
\hline
\end{tabular}

aSNPs: estimated LD values (D', LOD score and $r 2$ ) between polymorphism pairs. SNP 1: g.345G>A; SNP 2: g.1726C >T; SNP 3: g.1836G>A; and SNP 4: g.1838A>G 
Table 4 - Haplotype (Hap), haplotype frequency and standard srror of four SNPs in the lysozyme gene within the studied population

\begin{tabular}{|c|c|c|c|c|c|c|}
\hline \multirow[t]{2}{*}{ Haplotype } & \multicolumn{4}{|c|}{ SNPS $^{a}$} & \multirow{2}{*}{ Frequency } & \multirow{2}{*}{ Standard Error } \\
\hline & SNP 1 & SNP 2 & SNP 3 & SNP 4 & & \\
\hline Hap 1 & G & C & $G$ & A & 0,6461 & 0,0042 \\
\hline Hap 2 & G & C & A & G & 0,0379 & 0,0029 \\
\hline Hap 3 & G & T & G & A & 0,1227 & 0,0028 \\
\hline Hap 4 & A & C & G & A & 0,0872 & 0,0042 \\
\hline Hap 5 & A & C & A & G & 0,0655 & 0,0029 \\
\hline Hap 6 & A & $\mathrm{T}$ & G & A & 0,0406 & 0,0028 \\
\hline
\end{tabular}

a SNPs: SNP 1: g.345G>A; SNP 2: g.1726C>T; SNP 3: g.1836G>A; and SNP 4: g.1838A>G

value between SNP3 and SNP4, however, was equal to 1.000. The other two $r^{2}$ values (between SNP2 and SNP3, between SNP2 and SNP4) were equal to 0.023 . In this situation, $r^{2}$ and $D^{\prime}$ act differently, with $D^{\prime}$ still equal to 1 , but $r^{2}$ can be much smaller. It indicates that mutations (SNP2, SNP3 and SNP4) occur in different lineages, but with no recombination between them (between SNP2 and SNP3, between SNP2 and SNP4) (Flint-Garcia et al., 2003). The LOD score is a statistical test often used for linkage analysis in human, animal, and plant populations. Positive LOD scores indicate the presence of linkage. Furthermore, a LOD score greater than 3 is considered and evidence of linkage (Morton, 1955). All of the LOD scores here were positive, and, except for LOD between SNP1 and SNP 2, all of which were greater than 3 . This demonstrated the linkage among these SNPS.

Using PHASE computer program, haplotypes were reconstructed in the studied population. Six different haplotypes were detected in the population (Table 4). The dominant haplotype was haplotype 1 (GCGA), with the highest frequency (0.6461). Haplotype 3 (GTGA), with a frequency of 0.1227 , ranked second. The frequency of haplotype 2 (GCAG) was the lowest (0.0379).

\section{Effects of individual SNPs and haplotypes on the production traits}

The effects of the individual SNPs on the two production traits were analyzed (Table 5 ). At the P1 locus, the chickens with genotype GA had significantly higher16-week BW than those with GG and $A A(p<0.05)$, while individuals with the genotype GG had significantly higher16-week BW than those with $A A(p<0.05)$. It demonstrates that the allele $G$ and heterozygote at this locus may have the positive effects on16-week BW in the Langshan chicken population. The results are different from the previous research (Hou et al., 2010). It may be concluded that the breed factor affected the effects of lysozyme gene polymorphisms on production traits. At the $\mathrm{P} 2$ locus, the individuals with the genotypes $A C$ (the SNPs combination is CC-GA-AG) and BB (the SNPs combination is TT-GG-AA) presented significantly higher 16-week BW than those with CC (the SNPs combination is CC-AA-GG). Neither of the two loci (P1 and P2) of the lysozyme gene were associated with the total numbers of eggs produced in 300 days in the Langshan chicken population ( $p>0.05$ ). In this study, protein structure and sequence were not changed by the mutations detected, but these mutations did affect the chicken's production traits. There were many other similar studies were reported (Komar, 2007a,b). For example, a silent mutation of the MDR1 gene led to substrate specificity change (Kimchi-Sarfaty et al., 2007), synonymous mutations of the BMP7 gene affected cattle's body weight (Huang et al., 2013), a synonymous mutation of thelGF2 gene was found to be connected with body weight and egg production in Langshan chicken population (Yan et al., 2015). Accordingly, it would be interesting to explore the molecular mechanism of the relationship of the synonymous mutations with the animals' productive performance.

Table 5 - Associations between the four SNPs and two production traits in the studied Langshan chicken population

\begin{tabular}{lcccc}
\hline Loci & Genotypes & Number & \multicolumn{2}{c}{ Traits ( mean \pm standard error) } \\
\cline { 4 - 5 } & & & 16 -week BW $(\mathrm{kg})$ & 300-day EN \\
\hline \multirow{3}{*}{ P1 } & GG & 210 & $1.551 \pm 0.0103^{\mathrm{b}}$ & $87.880 \pm 1.3970$ \\
(SNP1) & $\mathrm{GA}$ & 64 & $1.611 \pm 0.0133^{\mathrm{a}}$ & $93.080 \pm 2.2430$ \\
& $\mathrm{AA}$ & 26 & $1.503 \pm 0.0286^{\mathrm{c}}$ & $95.310 \pm 3.3460$ \\
& 'p value & & $\mathrm{p}=0.001$ & $\mathrm{p}=0.054$ \\
& $\mathrm{AA}$ & 164 & $1.560 \pm 0.0116^{\mathrm{ab}}$ & $88.240 \pm 1.5490$ \\
$\mathrm{P2}$ & $\mathrm{AB}$ & 66 & $1.529 \pm 0.0174^{\mathrm{ab}}$ & $90.390 \pm 2.4090$ \\
(SNP & $\mathrm{BB}$ & 16 & $1.591 \pm 0.0398^{\mathrm{a}}$ & $92.250 \pm 5.9910$ \\
2/3/4) & $\mathrm{AC}$ & 45 & $1.605 \pm 0.0169^{\mathrm{a}}$ & $92.130 \pm 2.7260$ \\
& $\mathrm{CC}$ & 9 & $1.500 \pm 0.0408^{\mathrm{b}}$ & $92.110 \pm 5.6230$ \\
& 1 $\mathrm{p}$ value & & $\mathrm{p}=0.043$ & $\mathrm{p}=0.725$ \\
\hline
\end{tabular}

Values with different superscript letters $(a, b, a b, c)$ within the same column differ significantly at $(p<0.05)$.' The F-test for genotype effect. BW: body weight, EN: egg number 
Table 6 - Associations between combined haplotypes (Hap) of four SNPs and two production traits of Langshan chickens

\begin{tabular}{|c|c|c|c|c|}
\hline \multirow{2}{*}{ ID } & \multirow{2}{*}{ Combination of haplotypes } & \multirow{2}{*}{ Number of combination } & \multicolumn{2}{|c|}{ Traits ( mean \pm standard error) } \\
\hline & & & 16-week BW (kg) & 300-day EN \\
\hline 1 & Нар3-Нар6 & 6 & $1.680 \pm 0.0536^{a}$ & $89.830 \pm 9.7820$ \\
\hline 2 & Hap1-Hap5 & 24 & $1.630 \pm 0.0168^{\mathrm{ab}}$ & $91.080 \pm 3.5030$ \\
\hline 3 & Hap1-Hap2 & 12 & $1.606 \pm 0.0318^{\mathrm{ab}}$ & $92.000 \pm 6.5750$ \\
\hline 4 & Hap1-Hap4 & 18 & $1.599 \pm 0.0252^{\mathrm{ab}}$ & $95.560 \pm 4.2370$ \\
\hline 5 & Нар6-Нар6 & 2 & $1.595 \pm 0.1550^{\mathrm{ab}}$ & $110.500 \pm 7.5000$ \\
\hline 6 & Hap1-Нар6 & 12 & $1.581 \pm 0.0339^{\mathrm{ab}}$ & $98.420 \pm 4.6050$ \\
\hline 7 & Hap1-Нар1 & 140 & $1.559 \pm 0.0129^{\mathrm{ab}}$ & $87.200 \pm 1.6860$ \\
\hline 8 & Hар2-Hap5 & 4 & $1.540 \pm 0.0679^{\mathrm{ab}}$ & $82.750 \pm 10.4430$ \\
\hline 9 & Hар4-Hap5 & 8 & $1.536 \pm 0.0624^{\mathrm{ab}}$ & $97.750 \pm 5.3910$ \\
\hline 10 & Нар3-Нар3 & 8 & $1.523 \pm 0.0536^{\mathrm{ab}}$ & $89.500 \pm 9.3240$ \\
\hline 11 & Нар1-Нар3 & 48 & $1.521 \pm 0.0214^{\mathrm{ab}}$ & $88.310 \pm 2.9220$ \\
\hline 12 & Нар4-Hар6 & 6 & $1.488 \pm 0.0507^{\mathrm{ab}}$ & $91.000 \pm 7.8660$ \\
\hline 13 & Hap5-Hap5 & 3 & $1.470 \pm 0.0902^{b}$ & $103.670 \pm 4.6310$ \\
\hline 14 & Hар2-Hар2 & 2 & $1.465 \pm 0.0450^{b}$ & $93.500 \pm 6.5000$ \\
\hline \multirow[t]{2}{*}{15} & Нар4-Hap4 & 7 & $1.464 \pm 0.0485^{b}$ & $88.290 \pm 7.5200$ \\
\hline & ${ }^{1} p$ value & & $p=0.043$ & $p=0.573$ \\
\hline
\end{tabular}

Values with different superscript letters $(a, b, a b)$ within the same column differ significantly at $(p<0.05)$. ${ }^{1} \mathrm{~F}$-test for combined haplotype effect. BW: body weight, EN: egg number

There were six unique haplotypes for the lysozyme gene (Table 4), and 15 haplotype combinations were identified in the studied population (Table 6). In addition, the relationships between these 15 haplotype combinations with the Langshan chicken's production traits are demonstrated in Table 6. No associations were found between haplotype combination and 300-day EN ( $p>0.05)$, while the effects of these haplotype combinations on 16-week BW were found to be significant $(p<0.05)$. The chickens with combined haplotype Hap3-Hap6 (GA-TT-GG-AA) presented the highest body weight. This result is consistent with previous findings on the effect of individual SNPs on chicken's body weight, and the SNP1-GA and SNP2,3,4BB genotypes (TT-GG-AA) (chickens with AC genotype were the heaviest, but the difference between $A C$ and BB chickens was not significant) were associated with higher body weight (Table 5). The interactions between the individual SNPs may influence the effect of haplotypes, and the inheritance of combined haplotype was more efficient than that of individual SNP (Fallin et al., 2001). Therefore, the combined haplotype Hap3Hap6 (GA-TT-GG-AA) may be used as a molecular marker in the future for the selection for higher body weight in Langshan chicken. In addition, neither the individual SNPs nor the haplotype combinations in the lysozyme gene were found to be connected with 300day EN. However, because other egg parameters, such as egg weight and age at first egg, were not included in the research, further studies are needed before it is confirmed that the lysozyme gene has no effects on the chicken's egg production.

\section{CONCLUSIONS}

In summary, four SNPs, six haplotypes and 15 combined haplotypes of the lysozyme gene of a Chinese native chicken breed (Langshan chicken) were reported for the first time, and their associations with the chicken's productive parameters were analyzed. The results revealed that the combined haplotype Hap3-Hap6 (GA-TT-GG-AA) may be used as a molecular marker in the future for the selection of higher body weight in Langshan chickens. However, before confirming the lysozyme gene as a selection marker for all chicken populations, further studies on the molecular mechanisms and on the bioactivity of this gene in other chicken breeds are required.

\section{CONFLICT OF INTEREST}

We certify that there is no conflict of interest with any financial organization regarding the material discussed in the manuscript.

\section{ACKNOWLEDGMENTS}

This research was supported by the Science \& Technology Industrialization (Agriculture) Program of Nantong (No. CL2009002, No. HL2014024), Qing Lan Project of Jiangsu Province, Jiangsu Overseas Research \& Training Program for University Prominent Young \& Middle-aged Teachers and Presidents, "333 high-level personnel training project" of Jiangsu Province, Topnotch Academic Programs Project of Jiangsu Higher 
Education Institutions (TAPP), A Project Funded by the Priority Academic Program Development of Jiangsu Higher Education Institutions (PAPD).

\section{REFERENCES}

Baldacci P, Royal A, Cami B, Perrin F, Krust A, Garapin A, et al. Isolation of the lysozyme gene of chicken. Nucleic Acids Research 1979;6:26672681.

Barrett JE, Fry B, Maller J, Daly MJ. Haploview: analysis and visualization of LD and haplotype maps. Bioinformatics 2005;21:263-265.

Bonifer C, Vidal M, Grosveld F, Sippel AE. Tissue specific and position independent expression of the complete gene domain for chicken lysozyme in transgenic mice. The EMBO Journal 1990;9:2843-2848.

Botstein D, White RL, Skolnick M, Davis RW. Construction of a genetic linkage map inman using restriction fragment length polymorphisms. American Journal of Human Genetics 1980;32:314-331.

Callewaert L, Michiels CW. Lysozymes in the animal kingdom. Journal of Biosciences 2010;35:127-160.

Fallin D, Cohen A, Essioux L, Chumakov I, Blumenfeld M, Cohen D, et al. Genetic analysis of case/control data using estimated haplotype frequencies: application to APOE locus variation and Alzheimer's disease. Genome Research 2001;11:143-151.

Flint-Garcia SA, Thornsberry JM, Buckler ES 4th. Structure of linkage disequilibrium in plants. Annual Review of Plant Biology 2003;54:357374.

Grunclovà L, Fouquier H, Hypsa V, Kopácek P. Lysozyme from the gut of the soft tick Ornithodoros moubata: the sequence, phylogeny and postfeeding regulation. Developmental and Comparative Immunology 2003;27:651-660.

Hou QR, Wang JY, Wang HH, Li Y, Zhang GX, Wei Y, et al. Analysis of polymorphisms in exons of the LYZ gene and effect on growth traits of Jinghai Yellow chicken. International Journal of Poultry Science 2010;9:357-362

Huang $Y$, Zhang E, Wang J, Huai $Y$, Lan X, Ma L, et al. Two novel SNPs of SREBP1 gene are associatedwith body weight and average daily gain in bovine. Animal Biotechnology 2010;21:170-178.

Huang $Y Z$, Wang $X L$, He $H$, Lan $X Y$, Lei CZ, Zhang CL, et al. Identification and genetic effect of haplotype in the bovine BMP7 gene. Gene 2013:532:281-287.

Jung A, Sippel AE, Grez M, Schiitz G. Exons encode functional and structural units of chicken lysozyme. Proceedings of the National Academy of Sciences of the United States of America 1980;77:5759-5763.

Kimchi-Sarfaty C, Oh JM, Kim IW, Sauna ZE, Calcagno AM, Ambudkar SV, et al. A "silent" polymorphism in the MDR1 gene changes substrate specificity. Science 2007;315:525-528.

Komar AA. SNPs, silent but not invisible. Science 2007a;315:466-467.

Komar AA. Silent SNPs: impact on gene function and phenotype. Pharmacogenomics 2007b;8:1075-1080.

Lindenmaier W, Nguyen-Huu MC, Lurz R, Stratmann M, Blin N, Wurtz T, et al. Isolation and characterization of the chicken ovomucoid gene.
Proceedings of the National Academy of Sciences of the United States of America 1979;76:6196-6200.

Morton NE. Sequential tests for the detection of linkage. American Journal of Human Genetics 1955;7:277-318.

Müllenbach R, Lagoda PJ, Welter C. An efficient salt-chloroform extraction of DNA from blood and tissues. Trends in Genetics 1989;5:391-391.

Nagy S, Poczai P, Cernák I, Gorji AM, Hegedűs G, Taller J. PICcalc: an online program to calculate polymorphic information content for molecular genetic studies. Biochemical Genetics 2012;50:670-672

Nei M. Analysis of gene diversity in subdivided populations. Proceedings of the National Academy of Sciences of the United States of America $1973 ; 70: 3321-3323$

Nilsen IW, Myrnes B. The gene of chlamysin, a marine invertebratetype lysozyme, is organized similar to vertebrate but different from invertebrate chicken-type lysozyme genes. Gene 2001;269:27-32.

Peters CW, Kruse U, Pollwein R, Grzeschik KH, Sippel AE. The human lysozyme gene. Sequence organization and chromosomal localization. European Journal of Biochemistry 1989;182:507-516.

Phillips DC. The three-dimensional structure of an enzyme molecule. Scientific American 1966;215:78-90.

Roxström-Lindquist K, Terenius O, Faye I. Parasite-specific immune response in adult Drosophila melanogaster: a genomic study. EMBO Reports 2004;5:207-212.

Sassi P, Giugliarelli A, Paolantoni M, Morresi A, Onori G. Unfolding and aggregation of lysozyme: a thermodynamic and kinetic study by FTIR spectroscopy. Biophysical Chemistry 2011;158:46-53.

Schiitz G, Nguyen-Huu MC, Giesecke K, Hynes NE, Groner B, Wurtz T, et al. Hormonal control of egg white protein messenger RNA synthesis in the chicken oviduct. Cold Spring Harbor Symposia on Quantitative Biology $1978 ; 42: 617-624$

Stephens M, Smith N, Donnelly P. A new statistical method for haplotype reconstruction from population data. American Journal of Human Genetics 2001;69:978-989.

Sugimoto $Y$, Kamada $Y$, Tokunaga $Y$, Shinohara $H$, Matsumoto M, Kusakabe $\mathrm{T}$, et al. Aggregates with lysozyme and ovalbumin show features of amyloid-like fibrils. Biochemistry and Cell Biology 2011;89:533-544

Swaminathan R, Ravi VK, Kumar S, Kumar MV, Chandra N. Lysozyme: A model protein for amyloid research. Advances in Protein Chemistry and Structural Biology 2011;84:63-111.

Ursic Bedoya RJ, Mitzey AM, Obraztsova M, Lowenberger C. Molecular cloning and transcriptional activation of lysozyme encoding cDNAs in the mosquito Aedes aegypti. Insect Molecular Biology 2005;14:89-94.

Yan LJ, Fang XT, Liu Y, Zhang CL, Liu XX, Zhao J, et al. Effects of single and combined genotypes of MC4R and POU1F1 genes on two production traits in Langshan chicken. Molecular Biology Reports 2013;40:46454650 .

Yan LJ, Fang XT, Liu Y, Mauricio AE, Zhang CL, Chen $\mathrm{H}$. Exploring the genetic variants of insulin-like growth factor II gene and their associations with two production traits in Langshan chicken. Journal of Applied Animal Research; 2015 doi: 10.1080/09712119.2015.1124328. 
